\title{
Genetic characterization of some Turkish sheep breeds based on the sequencing of the Ovar-DRB1 gene in the major histocompatibility complex (MHC) gene region
}

\author{
Fulya Özdil ${ }^{1}$, Fatma İlhan ${ }^{2}$, and Raziye Işş ${ }^{1}$ \\ ${ }^{1}$ Dept. of Agricultural Biotechnology, Namık Kemal University, Tekirdağ, Turkey \\ ${ }^{2}$ Dept. of Animal Science, Selçuk University, Konya, Turkey \\ Correspondence: Fulya Özdil (fozdil@nku.edu.tr)
}

Received: 3 August 2018 - Revised: 13 November 2018 - Accepted: 22 November 2018 - Published: 6 December 2018

\begin{abstract}
In this research, Ovar-DRB1 gene in the major histocompatibility complex (MHC) gene region was surveyed by DNA sequencing in some of the native sheep breeds that are reared in Turkey. A total of 80 samples were collected from eight different Turkish native sheep breeds, and these samples were used for DNA sequencing.

The exon 2 region of $O v a r-D R B 1$ in the $\mathrm{MHC}$ gene region was polymerase chain reaction (PCR) amplified and sequenced. A total of 25 new alleles were revealed in the Ovar-DRB 1 gene in Turkish native sheep breeds with 24 variable sites; only 13 sites were parsimony informative. The average pairwise genetic distance was $0.029 \%$ for the Ovar-DRB1 gene exon 2 region. The sequence variations at eight different positions $(7026,7036,7040$, $7053,7059,7069,7131$ and 7214) are found in all of the studied samples. $\mathrm{G} \rightarrow \mathrm{C}$ transversion at position 7081 is only seen in Akkaraman sheep breed, whereas $\mathrm{T} \rightarrow \mathrm{C}$ transition at position 7097 is only seen in one sample from the Akkaraman breed. Overall, two main groups were detected among the 25 alleles from Turkish native sheep breeds. All Dağliç and Kivircik alleles and one allele from Karayaka, Malya and Sakiz are grouped together while all the other breeds are grouped in the other branch.
\end{abstract}

\section{Introduction}

Diseases are the most important factor which decrease the productivity in animal husbandry. Animal husbandry farms lose money due to diseases and deaths. Therefore, diseases must be reduced or eliminated. Cure is expensive and takes a long time after the animals are sick. Therefore, if the immune system of the animals can be developed, this may avoid or reduce the diseases.

The major histocompatibility complex (MHC) consists of a group of closely linked genes, and these genes are highly polymorphic. The main function of the MHC is to code specialized antigen-presenting receptor glycoproteins, which are known as histocompatibility molecules or MHC molecules (Dukkipati et al., 2006). The products of MHC genes play a key role in the immune system of the individuals. MHC genes have been extensively studied as candidate genes for disease resistance in many animal breeds (Dongxiao and Yuan, 2004). DRB genes have been commonly used and characterized in the MHC region. The second exon of the $D R B$ gene, in particular, has been the most widely studied gene region because it encodes peptide-binding sites that are extremely polymorphic (Blattman et al., 1993; Amills et al., 1996; Dongxiao and Yuan, 2004). The MHC of sheep is located on chromosome 20 and is abbreviated as Ovar or OLA genes (Brujeni et al., 2009).

Ovar-DRBI was found to be associated with gastrointestinal nematodes (Buitkamp et al., 1994; Schwaiger et al., 1994; Stear et al., 1996; Charon et al., 2002; Sayers et al., 2005) and BLV (bovine leukemia virus) induced ovine lymphoma (Nagaoka et al., 1999; Konnai et al., 2003a). Therefore, MHC loci have become attractive for studies of DNA markers 

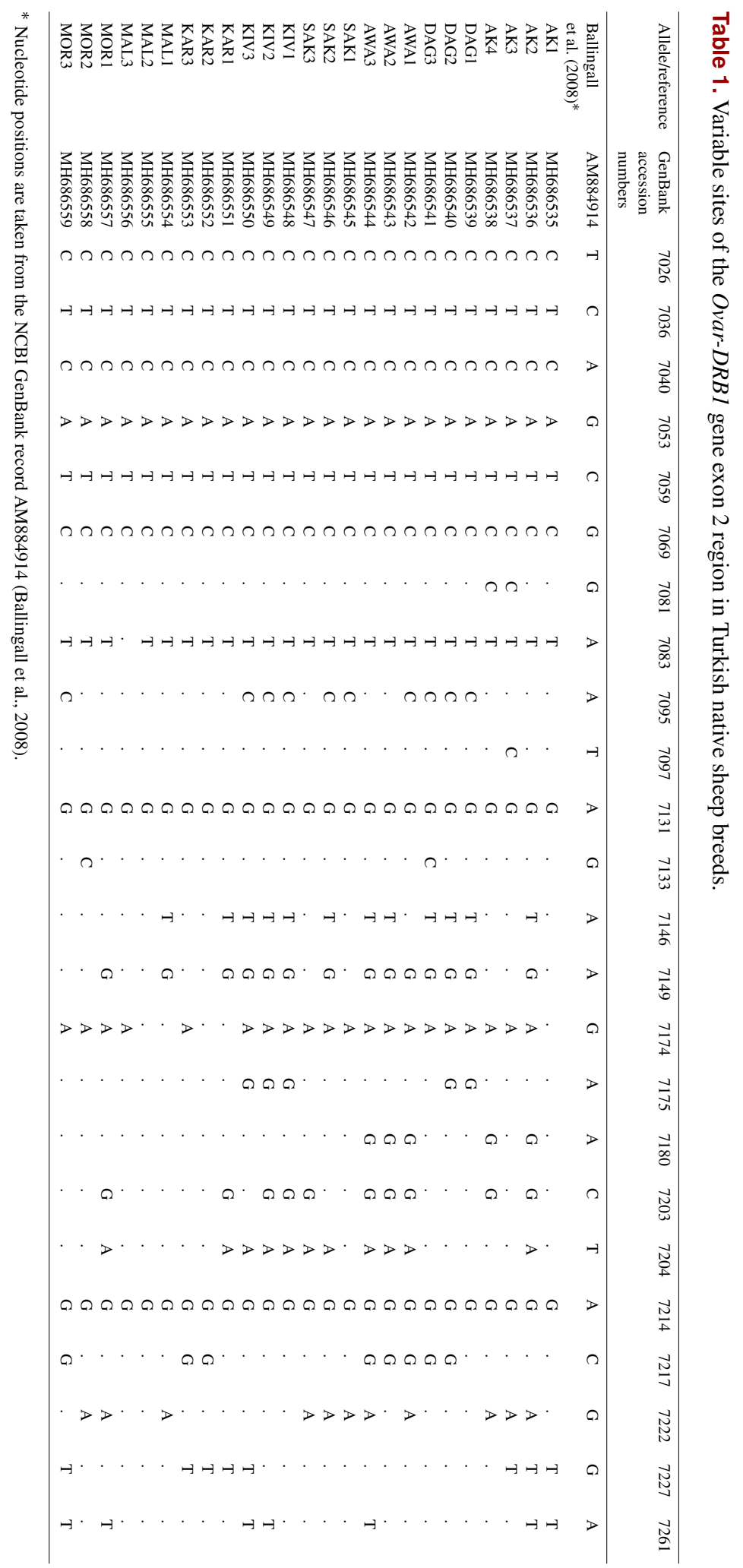
for gastrointestinal nematodes and BLV-induced ovine lymphoma (Dukkipati et al., 2006).

Genetic studies of variation in Ovar-MHC class II genes have shown that the $D R B$ locus is highly polymorphic (Schwaiger et al., 1994; Schwaiger and Epplen, 1995; Amills et al., 1996; Jugo and Vicario, 2000; Konnai et al., 2003b; Ballingall et al., 2008; Nikbakht et al., 2012; Lotfi et al., 2012; Shen et al., 2014; Takeshima et al., 2014). In particular, most of the polymorphism is found in exon 2 , which encodes the antigen-binding site (Escayg et al., 1997; Konnai et al., 2003b, c).

Many studies have been carried out on the exon 2 of the $D R B$ locus in different sheep breeds from all over the world (Blattman et al., 1993; Amills et al., 1996; Konnai et al. 2003b, c; Dongxiao and Yuan, 2004; Gruszczyńska et al., 2005; Shen et al., 2014). Nevertheless, there is little information about the MHC DRB polymorphism on Turkish native sheep breeds. To date, only two studies have been found in Turkish native sheep breeds (Bozkaya and Kurar, 2005; Ilhan et al., 2016).

\section{Material and methods}

In this research, eight different native sheep breeds that are reared in Turkey, including the Akkaraman, Dağliç, Awassi, Sakiz, Kivircik, Karayaka, Malya and Morkaraman (10 sheep per breed) breeds, were studied via DNA sequencing. The sampling locations and provinces are given on the map of Turkey (Fig. 1).

Total DNA was extracted from blood samples as described in Miller et al. (1988). The concentration and purification of genomic DNA was quantified with a NanoDrop ND-1000 spectrophotometer, and 20-30 ng of genomic DNA was used for the polymerase chain reaction (PCR). Ovar-DRB1 was amplified according to Konnai et al. (2003b). We used nested PCR to amplify the second exon of the DRB1 gene. The first PCR was performed with the primers OLA-ERB1 and HL031:

\section{- OLA-ERB1 (5'-CCGGAATTCCCGTCTCTGCAGCAC ATTTCTT-3')}

- HL031 (5'-TTTAAATTCGCGCTCACCTCGCCGCT$\left.3^{\prime}\right)$.

All the PCRs were performed in $25 \mu \mathrm{L}$ volume containing $2 \mu \mathrm{L}$ of $10 \times$ PCR buffer with $\mathrm{KCl}, 1.5 \mathrm{mM} \mathrm{MgCl}_{2}, 1.2 \mathrm{mM}$ of dNTP mix, $20 \mu \mathrm{M}$ of each primer, $2.5 \mathrm{U}$ of Taq polymerase and $20 \mathrm{ng}$ of DNA. The PCR amplification profile was initial denaturation for $5 \mathrm{~min}$ at $94^{\circ} \mathrm{C}, 94^{\circ} \mathrm{C}$ for $30 \mathrm{~s}$ ( 15 cycles), primer annealing at $50^{\circ} \mathrm{C}$ for $30 \mathrm{~s}$ and $1 \mathrm{~min}$ at $72^{\circ} \mathrm{C}$ for extension, and a final extension step at $72^{\circ} \mathrm{C}$ for $10 \mathrm{~min}$.

The second round of PCR was carried out using $5 \mu \mathrm{L}$ of the resultant mixture, with the addition of primers OLA-ERB1 and OLA-XRB1:

\section{- OLA-ERB1 (5'-CCGGAATTCCCGTCTCTGCAGCAC ATTTCTT-3')}
- OLA-XRB1 (5'-GCTCGAGCGCTGCACAGTGAAAC TC-3').

The thermal cycle profile started with an initial denaturation at $94^{\circ} \mathrm{C}$ for $5 \mathrm{~min}$ after $94^{\circ} \mathrm{C}$ for $30 \mathrm{~s}$, annealing at $60^{\circ} \mathrm{C}$ for $30 \mathrm{~s}$ and extension at $72^{\circ} \mathrm{C}$ for $1 \mathrm{~min}$ (30 cycles), followed by a final extension step at $72^{\circ} \mathrm{C}$ for $10 \mathrm{~min}$. The amplified PCR products were electrophoresed on $1 \%$ agarose gels to verify the fragment sizes.

In this study, genetic variability in the ovine $\mathrm{MHC}$, class II DRBl gene was analyzed by DNA sequencing. Amplicons were purified using the PCR cleanup kit and subjected to direct sequence analysis on an ABI Prism 3100 genetic analyzer (Applied Biosystems ${ }^{\mathrm{TM}}$, USA) using standard protocols in order to verify the sequence variations. Sequences were aligned with BioEdit Sequence Alignment Editor with Clustal W multiple alignment modules (Hall, 1999). The phylogenetic analysis was performed using MEGA 6 Software (Molecular Evolutionary Genetic Analysis, version 6.0) (Tamura et al., 2013) and the tree was constructed by the maximum likelihood (ML) approach on the basis of genetic distance matrix (Felsenstein, 1981).

\section{Results}

We analyzed the DNA sequence polymorphism of the Ovar$D R B 1$ gene in the MHC gene region in a total of 80 animals from eight different native Turkish sheep breeds: Akkaraman (AK), Dağliç (DAG), Awassi (AWA), Sakiz (SAK), Kivircik (KIV), Karayaka (KAR), Malya (MAL) and Morkaraman (MOR). The highly polymorphic exon 2 region, which includes antigen recognition sites (ARSs) in the MHC gene region, was used for sequence analysis. The Ovar-DRB1 locus is $11.979 \mathrm{bp}$ long. We used $286 \mathrm{bp}$ (primers excluded) of the exon 2 region, which is widely used in molecular studies for comparing different ruminant breeds. A total of 25 different alleles were revealed for this segment in Turkish native sheep breeds with 24 variable sites (Table 1). Only 13 sites were parsimony informative. The average pairwise genetic distance was $0.029 \%$ for the Ovar-DRBl gene exon 2 region. The DNA sequences of the alleles were deposited in the NCBI GenBank database, and DNA sequence variations and GenBank numbers are given in Table 1. The exon 2 of Ovar-DRB1 gene was aligned, and the nucleotide positions were taken from Ballingall et al. (2008). The NCBI GenBank record AM884914 is taken for comparison of the nucleotide positions because the whole $D R B$ gene is given in this GenBank record.

The sequence variations at eight different positions (7026, 7036, 7040, 7053, 7059, 7069, 7131 and 7214) are found in all of the studied samples. $\mathrm{G} \rightarrow \mathrm{C}$ transversion at position 7081 is only seen in the Akkaraman sheep breed, whereas T 


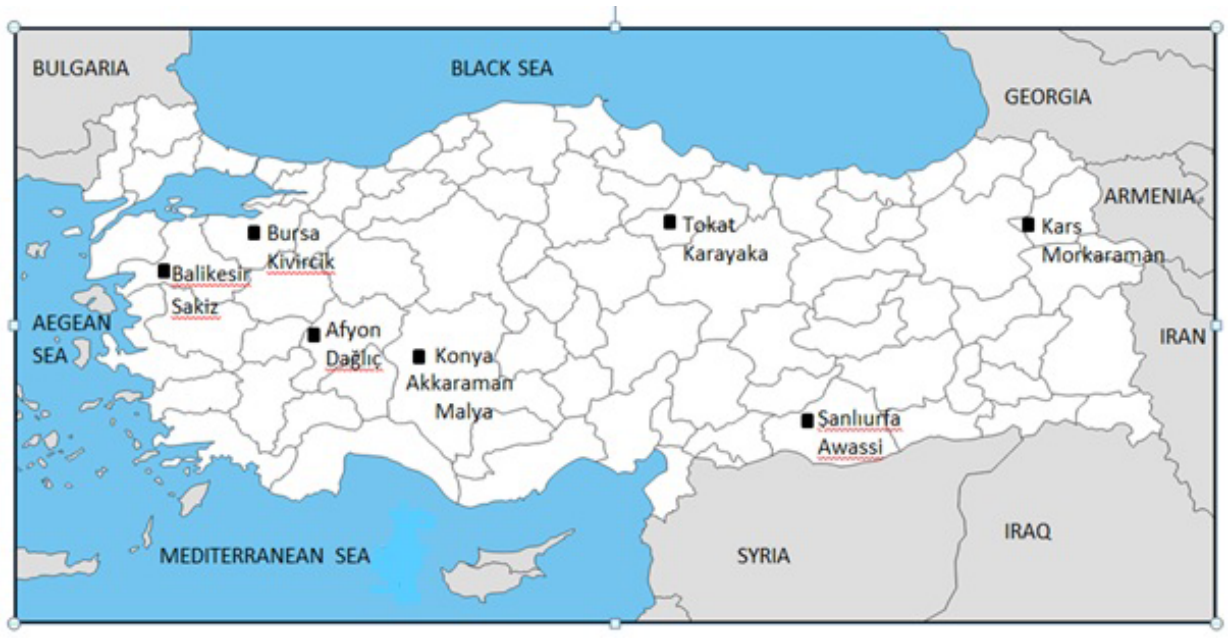

Figure 1. The location of the samples used for DNA sequencing (drawn by Fatma İhan).

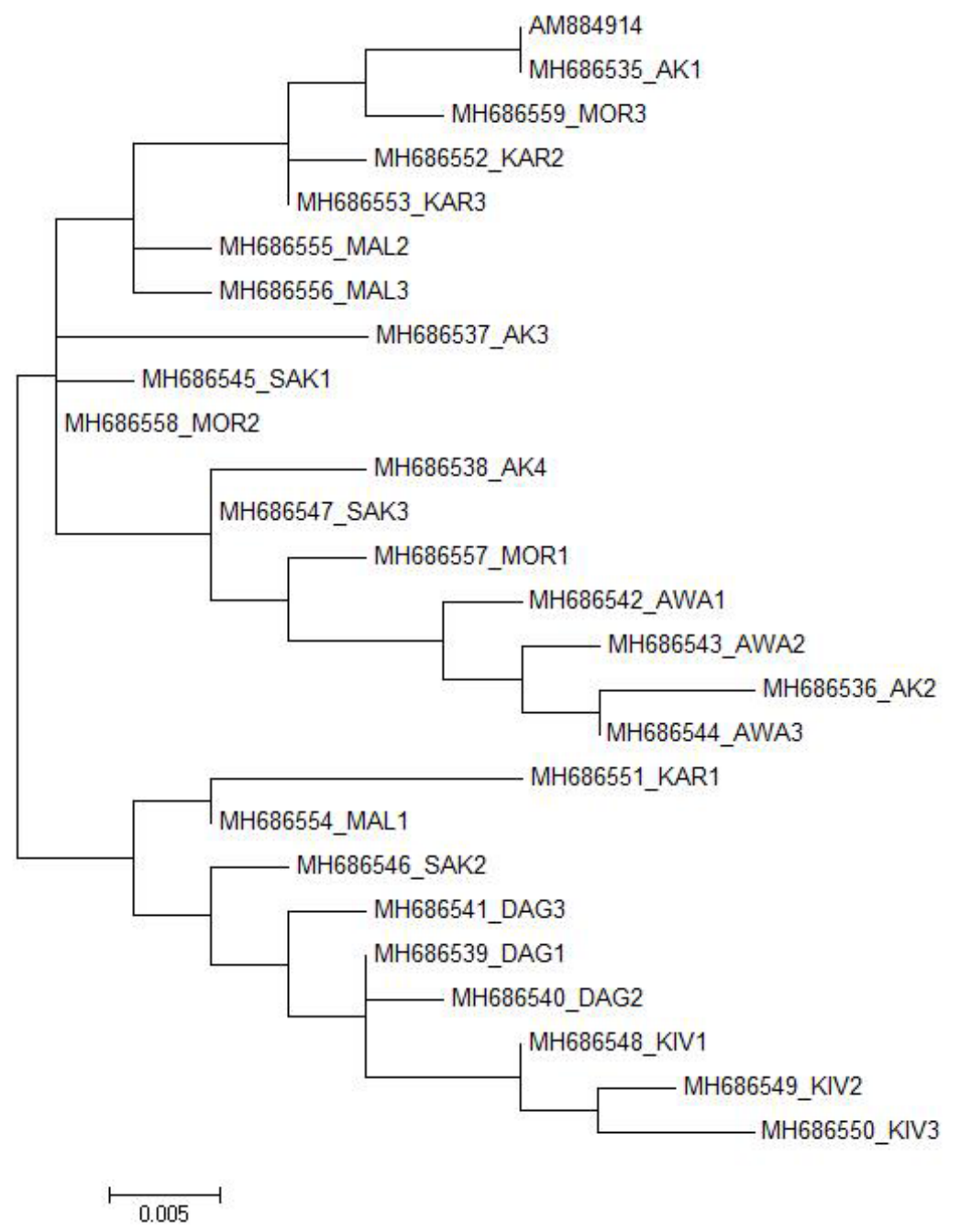

Figure 2. Maximum likelihood tree estimated under the HKY+I model for the Ovar-DRB1 gene exon 2 sequences of Turkish native sheep breeds with the AM884914 GenBank record. 
$\rightarrow \mathrm{C}$ transition at position 7097 is only seen in one sample from the Akkaraman breed. The other variable sites are given in Table 1.

The best DNA/protein model was the maximum likelihood model for constructing the phylogenetic trees using the MEGA 6 software.

In total, 25 different alleles were identified in exon 2 of the Ovar-DRBI gene of Turkish native sheep breeds. The 25 alleles were mainly clustered in two branches in the ML tree (Fig. 2). All Dağliç and Kivircik alleles and one allele from Karayaka, Malya and Sakiz were mainly clustered in one branch while all the other alleles were clustered in the other branch. The other breeds in the second branch did not diverge quite as strongly from each other, except for Awassi.

\section{Discussion}

The MHC gene family is a well-studied gene region in the vertebrate immune system and encodes antigen recognition proteins used in the adaptive immune response. Polymorphism studies of this gene have become very popular in the past decades. A variety of studies have shown that the MHC of sheep and goats introduced much more mutation and polymorphism than other genes.

In two of the recent studies of Turkish native sheep breeds, the restriction fragment length polymorphism (RFLP) pattern of the MHC gene region in the DRBI and DRB3 loci in Turkish sheep populations (Ilhan et al., 2016) and the presence of linkage disequilibrium between nine microsatellite loci in and outside the MHC gene region (Bozkaya and Kurar, 2005) were shown in Akkaraman, Awassi and Merinolandschaf sheep populations.

In the present study, we have used DNA sequencing of the Ovar-DRB1 gene exon 2 region to verify the genetic variation within and between some of the Turkish native sheep breeds. Overall, two main groups were detected among the 25 alleles from Turkish native sheep breeds (Fig. 2). All Dağliç and Kivircik alleles and one allele from Karayaka, Malya and Sakiz are grouped together while all the other breeds are grouped in the other branches.

In our study a total of 80 sheep from eight breeds of Turkey were analyzed and 25 new alleles were identified. These alleles were 98 to $96.1 \%$ identical at the nucleotide level in the GenBank records. The sequence variations at eight different positions (7026, 7036, 7040, 7053, 7059, 7069, 7131 and 7214) are found in all of the studied samples of Turkish native sheep breeds. These variable sites are found as fixed alleles in Turkish native sheep breeds.

In addition to previous findings on the exon 2 of Ovar$D R B 1$ gene, we report here a sequence analysis of this region in Turkish native sheep breeds and compare the results with published records. Our data show that two main groups were detected in Turkish native sheep breeds. Therefore, it is highly important to identify the genetic structure of Turkish native sheep breeds and improve strategies to conserve them in their local areas. Thus, we contribute to the National Sheep and Goat Breeding Project of Turkey with this study.

Data availability. In the file the photo of the PCR product, Bioedit Sequence Alignment results of some of the samples and the sequence results of the studied samples are given in the Supplement.

Supplement. The supplement related to this article is available online at: https://doi.org/10.5194/aab-61-475-2018-supplement.

Author contributions. All authors made substantial contributions to each step of the experimental procedure and manuscript preparation. FI performed the sampling. FÖ supervised all stages of the experimental study. FÖ and FI performed the laboratory analysis. FÖ and RI analyzed the molecular data. All the authors wrote and prepared the manuscript. All the revisions were done by FÖ and RI.

Competing interests. The authors declare that they have no conflict of interest.

Acknowledgements. We thank Selçuk University, The Scientific Research Projects Coordinating Office (project no: 12401025; principal investigator: Fulya Özdil).

Edited by: Steffen Maak

Reviewed by: two anonymous referees

\section{References}

Amills, M., Francino, O., and Sanchez, A.: A PCR-RFLP typing method for the caprine MHC class II DRB gene, Vet. Immunol. Immunop., 55, 255-260, 1996.

Ballingall, K. T., Fardoe, K., and McKeever, D. J.: Genomic organisation and allelic diversity within coding and non-coding regions of the Ovar-DRB1 locus, Immunogenetics, 60, 95-103, 2008.

Blattman, A. N., Hulme, D. J., Kinghorn, B. P., Woolaston, R. R., Gray, G. D., and Beh, K. J.: A search for associations between major histocompatibility complex restriction fragment length polymorphism bands and resistance to Haemonchus contortus infection in sheep, Anim. Genet., 24, 277-282, 1993.

Bozkaya, F. and Kurar, E.: Linkage disequilibrium between MHClinked microsatellite loci in White Karaman, Awassi and Merinolandschaf sheep breeds, F.Ü. Sağlık Bil. Derg., 19, 57-61, 2005.

Brujeni, N. G. H., Emam, M., Mahmoudzadeh, H., Hamedmonfared, E., Talebnia Jahromi, R., and Rezaei, H.: Typing of OvarDRB1 second exon with PCR-RFLP technique in Iranian Shaul Sheep, Iran. J. Vet. Res., 10, 250-254, 2009.

Buitkamp, J., Gostomski, D., Schwaiger, F. W., Stear, M. J., and Epplen, J. T.: Association between the ovine major histocompat- 
ibility complex DRB1 gene and resistance to Ostertagia circumcincta infestation, Anim. Genet., 25, 59-60, 1994.

Charon, K. M., Moskwa, B., Rutkowski, R., Gruszczyńska, J., and Swiderek, W.: Microsatellite polymorphism in DRB1 gene (MHC class II) and its relation to nematode faecal egg count in Polish Heath sheep, J. Anim. Feed Sci., 11, 47-58, 2002.

Dongxiao, S. and Yuan, Z.: Polymorphisms of the second exon of MHC-DRB gene in Chinese local sheep and goat, Biochem. Genet., 42, 385-390, 2004.

Dukkipati, V. S. R., Blair, H. T., Garrick, D. J., and Murray, A.: Ovar-MHC- ovine major histocompability complex: structure and gene polymorphisms, Genet. Mol. Res., 5, 581-608, 2006.

Escayg, A. P., Hickford, J. G., and Bullock, D. W.: Association between alleles of the ovine major histocompatibility complex and resistance to footrot, Res. Vet. Sci., 63, 283-287, 1997.

Felsenstein, J.: Evolutionary trees from DNA sequences: A maximum likelihood approach, J. Mol. Evol., 17, 368-376, 1981.

Gruszczyńska, J., Brokowska, K., Charon, K. M., and Swiderek, W. P.: Restriction fragment length polymorphism of exon 2 OvarDRB1 gene in Polish Heath Sheep and Polish Lowland Sheep, J. Appl. Genet., 46, 311-314, 2005.

Hall, T. A.: BioEdit: a user-friendly biological sequence alignment editor and analysis program for Windows 95/98/NT, Nucl. Acids. Symp. Ser., 41, 95-98, 1999.

Ilhan, F., Keskin, I., and Tozluca, A.: Identification of genetic variation in the major histocompatibility complex gene region in Turkish sheep breeds, S. Afr. J. Anim. Sci., 46, 366-372, 2016.

Jugo, B. M. and Vicario, A.: Single-strand conformational polymorphism and sequence polymorphism of Mhc-DRB in Latxa and Karrantzar sSheep: implications for caprinae phylogeny, Immunogenetics, 51, 887-897, 2000.

Konnai, S., Takesima, S. N., Tajima, S., Yin, S. A., Okada, K., Onuma, M., and Aida, Y.: The influence of ovine MHC class II DRB1 alleles on immune response in bovine leukemia virus infection, Microbiol. Immunol., 47, 223-232, 2003a.

Konnai, S., Nagaoka, Y., Takesima, S., Onuma, M., and Aida, Y.: Technical note: DNA typing for ovine MHC-DRB1 using polymerase chain reaction-restriction fragment lenght polymorphism (PCR-RFLP), J. Dairy Sci., 86, 3362-3365, 2003b.

Konnai, S., Nagaoka, Y., Takesima, S., Onuma, M., and Aida, Y.: Sequences and diversity of 17 new Ovar-DRB1 alleles from three breeds of sheep, Eur. J. Immunogenet., 30, 275-282, $2003 \mathrm{c}$.

Lotfi, M., Nassiri, M. T. B., Roshanfekr, H., and Fayazi, J.: Polymorphism of Ovar-DRB1 Second Exon with PCR-RFLP Technique in Arabi Sheep Population of Khuzestan Province, J. Anim. Vet. Adv., 11, 343-345, 2012.
Miller, S. A., Dykes, D. D., and Polesky, H. F.: A simple salting out procedure for extracting DNA from human nucleated cells, Nucleic Acids Res., 16, 1215, 1988.

Nagaoka, Y., Kabeya, H., Onuma, M., Kasai, N., Okada, K., and Aida, Y. Ç.: Ovine MHC class II DRB1 alleles associated with resistance or susceptibility to development of bovine leukemia virus-induced ovine lymphoma, Cancer Res., 59, 975-981, 1999.

Nikbakht, G., Rezaii, H., Stear, M. J., Talebi, M. A., and Mahmoudzadeh, H.: Allelic polymorphism in the second exon of Ovar-DRB1 in fat-tailed sheep, Vet. J., 192, 547-549, 2012.

Sayers, G., Good, B., Hanrahan, J. P., Ryan, M., Angles, J. M., and Sweeney, T.: Major histocompatibility complex DRB1 gene: its role in nematode resistance in Suffolk and Texel sheep breeds, Parasitology, 131, 403-409, 2005.

Schwaiger, F. W. and Epplen, J. T.: Exonic MHC-DRB polymorphisms and intronic simple repeat sequences: Janus' faces of DNA sequence evolution, Immunol. Rev., 143, 199-224, 1995.

Schwaiger, F. W., Weyers, E., Buitkamp, J., Ede, A. J., Crawford, A., and Epplen, J. T.: Interdependent MHC-DRB exon plusintron evolution in artidactyls, Mol. Biol. Evol., 11, 239-249, 1994.

Shen, H., Han, G., Jia, B., Jiang, S., and Du, Y.: MHCDRB1/DQB1 Gene polymorphism and its association with resistance/susceptibility to cystic echinococcosis in Chinese Merino Sheep, J. Parasitol. Res., 272601, https://doi.org/10.1155/2014/272601, 2014.

Stear, M. J., Bairden, K., Bishop, S. C., Buitkamp, J., Epplen, J. T., Gostomski, D., Mckellar, Q. A., Schwaiger, F. W., and Wallace, D. S.: An ovine lymphocyte antigen is associated with reduced faecal egg counts in four-month-old lambs following natural, predominantly Ostertagia circumcincta infection, Int. J. Parasitol., 26, 423-428, 1996.

Takeshima, S. N., Miyasaka, T., Polat, M., Kikuya, M., Matsumoto, Y., Mingala, C. N., Villanueva, M. A., Salces, A. J., Onuma, M., and Aida, Y.: The great diversity of major histocompatibility complex class II genes in Philippine native cattle, Meta. Gene., 2, 176-190, 2014.

Tamura, K., Stecher, G., Peterson, D. Filipski, A., and Kumar, S.: MEGA6: Molecular evolutionary genetics analysis version 6.0, Mol. Biol. Evol., 30, 2725-2729, 2013. 